\title{
Eyelid Carcinoma pT3 TNM Finding v8
}

National Cancer Institute

\section{Source}

National Cancer Institute. Eyelid Carcinoma pT3 TNM Finding v8. NCI Thesaurus. Code C140497.

Eyelid carcinoma with tumor measuring more than $20 \mathrm{~mm}$ but $30 \mathrm{~mm}$ or less in greatest dimension. (from AJCC 8th Ed.) 